\title{
A dominance shift from the zebra mussel to the invasive quagga mussel may alter the trophic transfer of metals
}

\author{
Jonathan Matthews ${ }^{a}$, Aafke M. Schipper ${ }^{a}$, A. Jan Hendriks ${ }^{\text {a }}$, T.T. Yen Le ${ }^{\text {a }}$ \\ Abraham bij de Vaate ${ }^{b}$, Gerard van der Velde ${ }^{\text {c, d }}$, Rob S.E.W. Leuven ${ }^{\text {a, * }}$ \\ a Radboud University, Institute for Water and Wetland Research, Department of Environmental Science, P.O. Box 9010, 6500 GL Nijmegen, The Netherlands \\ ${ }^{\mathrm{b}}$ Waterfauna Hydrobiologisch Adviesbureau, Oostrandpark 30, 8212 AP Lelystad, The Netherlands \\ ${ }^{\mathrm{c}}$ Naturalis Biodiversity Center, P.O. Box 9517, 2300 RA Leiden, The Netherlands \\ ${ }^{\mathrm{d}}$ Radboud University, Institute for Water and Wetland Research, Department of Animal Ecology and Ecophysiology, P.O. Box 9010, 6500 GL Nijmegen, \\ The Netherlands
}

\section{A R T I C L E I N F O}

\section{Article history:}

Received 3 November 2014

Received in revised form

18 March 2015

Accepted 21 March 2015

Available online

\section{Keywords:}

Food-web

Non-native

Species replacement

Dreissenids

Predators

\begin{abstract}
A B S T R A C T
Bioinvasions are a major cause of biodiversity and ecosystem changes. The rapid range expansion of the invasive quagga mussel (Dreissena rostriformis bugensis) causing a dominance shift from zebra mussels (Dreissena polymorpha) to quagga mussels, may alter the risk of secondary poisoning to predators. Mussel samples were collected from various water bodies in the Netherlands, divided into size classes, and analysed for metal concentrations. Concentrations of nickel and copper in quagga mussels were significantly lower than in zebra mussels overall. In lakes, quagga mussels contained significantly higher concentrations of aluminium, iron and lead yet significantly lower concentrations of zinc66, cadmium111, copper, nickel, cobalt and molybdenum than zebra mussels. In the river water type quagga mussel soft tissues contained significantly lower concentrations of zinc66. Our results suggest that a dominance shift from zebra to quagga mussels may reduce metal exposure of predator species.
\end{abstract}

๑) 2015 Elsevier Ltd. All rights reserved.

\section{Introduction}

Bioinvasions are one of the major, and growing, causes of biodiversity loss (European Commission, 2013). The EU Biodiversity Strategy (European Commission, 2011), and the International Union for Conservation of Nature (IUCN) guidelines for the prevention of biodiversity loss caused by invasive non-native species, stress the need to identify the most harmful invaders (ISSG, 2000; Katsanevakis et al., 2013). Currently, the rapid range expansion of the quagga mussel (Dreissena rostriformis bugensis) is resulting in a dominance shift from the established zebra mussel (Dreissena polymorpha) to the quagga mussel (Diggins, 2001; Bonhof et al., 2009; De Rooij et al., 2009; Bij de Vaate, 2010; Heiler et al., 2012; Matthews et al., 2014; Bij de Vaate et al., 2014). Both dreissenid freshwater bivalves appear to be invasive in Western Europe and

\footnotetext{
* Corresponding author.

E-mail addresses: J.Matthews@science.ru.nl (J. Matthews), A.Schipper@science. ru.nl (A.M. Schipper), A.J.Hendriks@science.ru.nl (A.J. Hendriks), yenle@science.ru. nl (T.T. Yen Le), vaate@planet.nl (A. bij de Vaate), g.vandervelde@science.ru.nl (G. van der Velde), r.leuven@science.ru.nl (R.S.E.W. Leuven).
}

North America (Neumann and Jenner, 1992; Mitchell et al., 1996; Watkins et al., 2007; Gonzalez and Downing, 1999; Ward and Ricciardi, 2010; Matthews et al., 2014), and are an important source of food for native water birds, fish, crayfish and crabs (Kelly et al., 2010; Mörtl et al., 2010; Van Eerden and De Leeuw, 2010; Bij de Vaate, 2010; Noordhuis et al., 2010; Matthews et al., 2014). Some waterfowl species have been reported to alter their dietary intake and migration patterns in response to the ready availability of zebra mussels (Petrie and Knapton, 1999).

The ability of both these mussel species to filter large quantities of water allows them to accumulate toxicants, which may lead to the secondary poisoning of native predator species (Rutzke et al., 2000; Kwon et al., 2006; Hogan et al., 2007; Mueting and Gerstenberger, 2010). Accumulation of toxicants may lead to mortality and sub-lethal effects such as altered growth, reproduction, and behaviour (Flemming and Trevors, 1989; Custer and Custer, 2000; Santore et al., 2002; Custer et al., 2003; Petrie et al., 2007). Metal accumulation has been implicated in many of these effects. For example, cadmium transfer from zebra mussels to the tufted duck (Aythya fuligula) has resulted in behavioural disturbances in adults, growth retardation, and embryonic mortality (De Kock and 
Bowmer, 1993). Selenium toxicity impacts staging, winter body condition and health of lesser and greater scaup (Aythya affinis and Aythya marila), diving ducks that feed primarily on dreissenids (Custer and Custer, 2000; Custer et al., 2003; Petrie et al., 2007). Accumulation of copper may cause mortality and sub lethal effects such as altered growth, reproduction, and behaviour in fish and macroinvertebrate species (Flemming and Trevors, 1989). High concentrations of zinc may result in calcium uptake inhibition in certain fish species (Santore et al., 2002). Moreover, lead has long been considered one of the most significant metals from the standpoint of environmental contamination and toxicology (Scheuhammer, 1987).

However, metal concentrations in mussel soft tissues may vary, depending on species-specific factors such as reproduction cycle, filtration rate, and ventilation rate (Kraak et al., 1991; Veltman et al., 2008). Therefore, a shift in dominance from established to newly invading mussel species may alter the trophic transfer of metals to native predators. Peer reviewed literature focussing on potential differences in accumulation of metals between the soft tissues of the quagga and zebra mussel is scarce, often inconclusive and limited to North America (Johns and Timmerman, 1998; Rutzke et al., 2000; Richman and Somers, 2005; Le et al., 2011). Moreover, studies reporting metal concentrations in quagga mussels are particularly rare. This article aims to (1) identify potential interspecies differences in metal concentrations between the invasive quagga and established zebra mussel; (2) identify potential intraspecies differences in metal concentrations in the soft tissues of quagga mussels in relation to shell size and water type (i.e., river or lake); (3) discuss the possible implications of these inter- and intraspecies differences in relation to a dominance shift from zebra mussels to invading quagga mussels for the trophic transfer of metals.

\section{Materials and methods}

\subsection{Field survey and chemical analyses}

Zebra and quagga mussels were collected by hand from groyne stones from four river locations and with a trawl net from two lake locations in the Netherlands (Fig. 1, Table 1). These sites were selected based on available evidence on the co-existence of the two species. Mussels were separated according to species and size class (small: <15 mm, medium: 15-22 mm, and large: $>22 \mathrm{~mm}$ ). The mussels were not depurated prior to extraction from their shells as this more accurately reflects metal exposure to predators. Mussel predators consume the entire mussel and are therefore exposed to both stomach contents and mussel tissue. Metal concentrations in dreissenid shells have been found to be orders of magnitude lower than in mussel soft tissue (Van der Velde et al., 1992). Therefore, metal concentrations in mussel shells were considered negligible and shells were not included in the analysis. The soft tissue was extracted from mussel shells and subsequently dried at $70{ }^{\circ} \mathrm{C}$ for $24 \mathrm{~h}$. Dried samples were then weighed using a Sartorius LA310s micro balance (Sartorius AG, Göttingen, Germany) to produce replicates of $0.2 \mathrm{~g}$ dry weight. The dried samples were digested with $4 \mathrm{ml} \mathrm{HNO}{ }_{3} 65 \%$ and $0.5 \mathrm{ml} \mathrm{H}_{2} \mathrm{O}_{2}$ in a Milestone Ethos D microwave. Following digestion, $100 \mathrm{ml}$ of high quality deionized water was added to each sample. In addition, blanks were prepared to allow for corrections to metal concentrations determined from mussel samples. Analysis of metal concentrations was undertaken using inductively coupled plasma mass spectroscopy (ICP MS) for aluminium ( $\mathrm{Al})$, chromium $(\mathrm{Cr})$, manganese $(\mathrm{Mn})$, iron $(\mathrm{Fe})$, cobalt (Co), nickel (Ni), copper (Cu), zinc (Zn66 and Zn68), arsenic (As), selenium (Se), molybdenum (Mo), cadmium (Cd111 and Cd112), tin $(\mathrm{Sn})$, mercury $(\mathrm{Hg})$, and lead $(\mathrm{Pb})$. We considered the complete

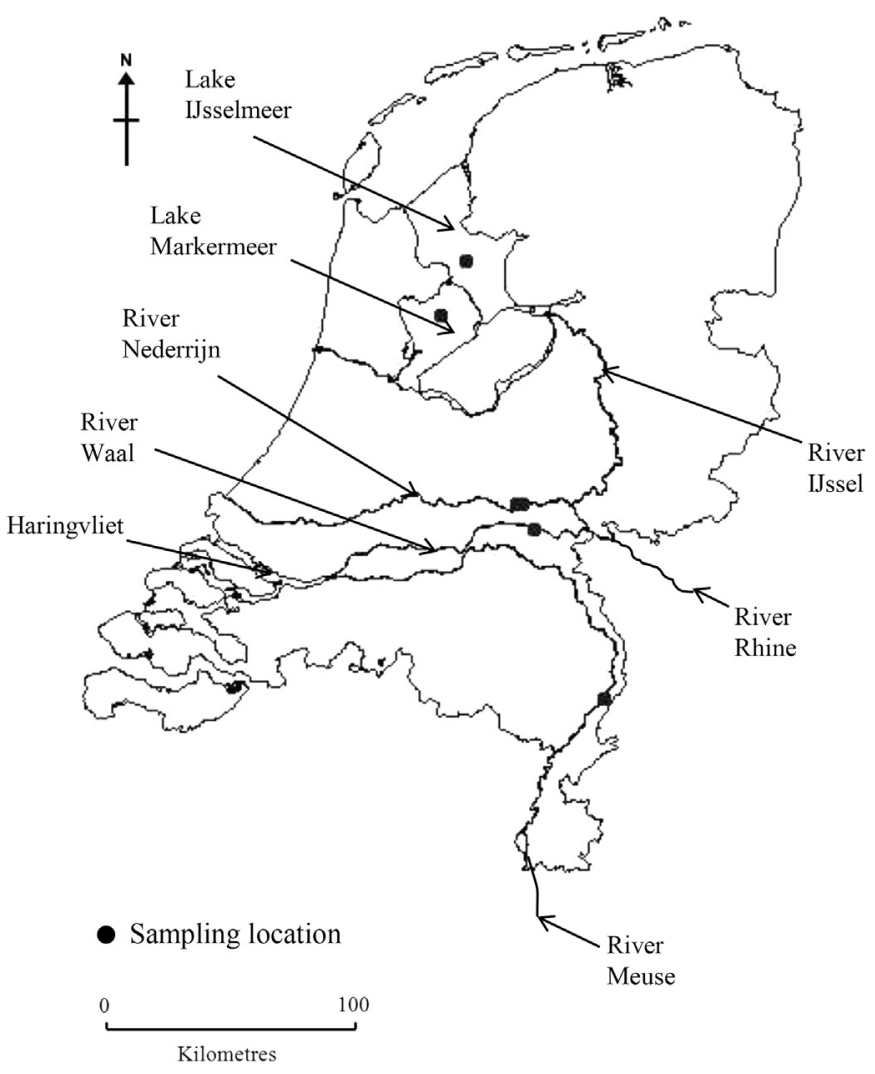

Fig. 1. Locations sampled during field surveys.

range of metals measured by ICP-MS as this gives the most complete insight into possible changes in metal exposure of predator species resulting from a dominance shift in prey species.

\subsection{Data analysis}

A number of comparisons were made to identify inter-species and intra-species differences in soft tissue metal concentrations (Tables 2 and 3). Data on metal concentrations were aggregated and compared according to mussel species, size class and origin of sampled material (water type and water body). Water bodies included in the analysis were the lakes IJsselmeer and Markermeer, and rivers Waal, Nederrijn, and Meuse (Fig. 1). In the inter-species comparisons, only paired samples were used (same location and time period). The number of samples for each species included in these analyses was, therefore, the same. Inter-species comparisons consisted of analyses (1) combining all size classes and locations, (2) per water type (river or lake) and combining size classes, and (3) per size class and combining all water types (Table 2). Intra-specific comparisons were made for the quagga mussel. In order to reduce possible bias due to differences in sampling period, only samples taken in 2009 and 2010 were used for this comparison. To obtain sufficient statistical power, concentrations were aggregated either by size class or by sampling location. This was done (1) per size class combining all locations, (2) for lake and river water types combining all size classes and aggregating data for all water bodies within each water type, (3) individual rivers combining all size classes, and (4) individual lakes combining all size classes (Table 3).

\subsection{Statistical analysis}

Potential differences between groups were tested for statistical 
Table 1

Sampling locations and number of individuals collected.

\begin{tabular}{|c|c|c|c|c|c|}
\hline Sampling location & Water type & Coordinates & Sampling period & Number of zebra mussels & Number of quagga mussels \\
\hline Ewijkse Plaat, River Waal & River & $\begin{array}{l}51^{\circ} 52^{\prime} 50.7^{\prime \prime} \mathrm{N} \\
23^{\circ} 27^{\prime} 30.7^{\prime \prime} \mathrm{E}\end{array}$ & October 2008 & 287 & 35 \\
\hline Lexkesveer, River Nederrijn & River & $\begin{array}{l}51^{\circ} 57^{\prime} 33.9^{\prime \prime} \mathrm{N} \\
5^{\circ} 41^{\prime} 22.7^{\prime \prime} \mathrm{E}\end{array}$ & April 2010 & 9 & 415 \\
\hline $\begin{array}{l}\text { Wageningen harbour, } \\
\text { River Nederrijn }\end{array}$ & River & $\begin{array}{l}51^{\circ} 57^{\prime} 41.7^{\prime \prime} \mathrm{N} \\
5^{\circ} 39^{\prime} 31.4^{\prime \prime} \mathrm{E}\end{array}$ & April 2010 & 162 & 64 \\
\hline Near Belfeld, River Meuse & River & $\begin{array}{l}51^{\circ} 19^{\prime} 13.6^{\prime \prime} \mathrm{N} \\
6^{\circ} 6^{\prime} \\
55.2^{\prime \prime} \mathrm{E}\end{array}$ & April 2010 & 90 & 598 \\
\hline Lake IJsselmeer & Lake & $\begin{array}{l}52^{\circ} 47^{\prime} 52.2^{\prime \prime} \mathrm{N} \\
5^{\circ} 19^{\prime} 24.9^{\prime \prime} \mathrm{E}\end{array}$ & $\begin{array}{l}\text { June, July, September } \\
\text { and November } 2009\end{array}$ & 1156 & 2471 \\
\hline Lake Markermeer & Lake & $\begin{array}{l}52^{\circ} 32^{\prime} 18.0^{\prime \prime} \mathrm{N} \\
5^{\circ} 15^{\prime} 20.1^{\prime \prime} \mathrm{E}\end{array}$ & July, November 2009 & 870 & 308 \\
\hline
\end{tabular}

significance using ANOVA or the non-parametric Mann Whitney test (IBM SPSS Statistics, release 20.0.0). Non parametric tests were applied if the data was not normally distributed and/or if non homogenous variance between groups was determined following log transformation. The Shapiro Wilk and Levene tests were applied to assess normality and equality of variance, respectively.

\section{Results}

\subsection{Inter-species differences in metal concentrations in soft tissues}

The overall comparison of the two species revealed significantly higher concentrations of nickel and copper in the zebra mussel than in the quagga mussel (Fig. 2A, Table 4). In the lake water type, zebra mussel soft tissues contained significantly higher concentrations of zinc66, cadmium111, copper, nickel, cobalt and molybdenum than quagga mussel soft tissue by a factor of 1.5-2.3. However, concentrations of aluminium, iron and lead in quagga mussel soft tissue were significantly higher than those in zebra mussel soft tissue, by factors of 1.7-1.9, respectively (Fig. 2B, Table 4). In the river water type zebra mussel soft tissues contained significantly higher concentrations of zinc66 (Fig. 2C, Table 4). For size classes, no significant differences between the two species were found (Fig. 2D-F).

\subsection{Intra-species differences in metal concentrations in soft tissue}

Iron, zinc66 and zinc68 were accumulated at significantly higher concentrations in quagga mussel soft tissue obtained from rivers than from lakes, by factors of 2.5, 1.5 and 1.8, respectively (Fig. 3, Table 5). No metals were present in significantly higher concentrations in quagga tissue obtained from lakes compared to rivers. The analysis of individual water bodies revealed no significant differences in metal concentration between quagga mussel soft tissues sampled from lake Markermeer and lake IJsselmeer (Table 5). Tissues of quagga mussels sampled from the river Meuse showed significantly higher concentrations of mercury, cadmium111, cadmium112, iron, manganese, cobalt, nickel, zinc66, zinc68, arsenic, selenium and tin than samples taken from the river Nederrijn (Table 5).

Table 2

Number of paired samples used in the analyses of inter-species differences in soft tissue metal concentrations.

\begin{tabular}{ll}
\hline Data aggregation per species & Number of paired samples analysed per metal \\
\hline Overall & 13 \\
Large size class & 3 \\
Medium size class & 5 \\
Small size class & 4 \\
Lake water type & 6 \\
River water type & 7 \\
\hline
\end{tabular}

\section{Discussion}

In the present study we investigated potential differences in soft tissue metal concentration between quagga and zebra mussels, as well as intra-species differences in quagga mussel metal concentrations in relation to water type and shell size. To that end, we collected and analysed the soft tissue of zebra and quagga mussels of different size classes originating from various water bodies in the Netherlands. In order to minimise bias resulting from temporal and spatial variation in sampling intensity, paired samples (i.e., same location and sampling period) were used for the species and size class comparisons. In order to reduce possible bias due to differences in sampling period in the intra-species comparisons of size and water body, only samples from the years 2009 and 2010 were used. Therefore, spatial and temporal variations in metal concentrations are unlikely to have influenced the results.

\subsection{Differences in soft tissue metal concentrations between quagga and zebra mussels}

A number of mainly American and Canadian studies on metal accumulation in dreissenid mussels support our findings. Richman and Somers (2005) found generally higher concentrations of zinc, nickel, copper, and cadmium in soft tissues of zebra mussels than in quagga mussels from the Niagara river, Canada. Our results also agree with the estimates of the dynamic bioaccumulation model developed by Le et al. (2011), as well as the results of a field study in Lake Ontario, Canada, where higher copper and zinc concentrations were found in zebra mussels (Johns and Timmerman, 1998). Moreover, mercury concentrations were similar in the two dreissenid species in lakes Mead, Mohave and Havasu, the United States, consistent with our results (Mueting and Gerstenberger, 2010). However, in a study examining seasonal and inter-annual variation, higher concentrations of cadmium were found in quagga mussels than zebra mussels sampled from the outflow of lake Ontario, Canada, contrasting with the results of this study (Johns and Timmerman, 1998). Moreover, Rutzke et al. (2000) found no statistical differences in a large set of soft tissue metal concentrations between quagga and zebra mussels sampled in June 1997 from lakes Erie and Ontario, Canada.

Table 3

Number of samples used in the analyses of intra-species differences of soft tissue metal concentrations in quagga mussels (Dreissena rostriformis bugensis).

\begin{tabular}{ll}
\hline Data aggregation & Locations and number of samples analysed per metal \\
\hline Lakes & IJsselmeer (3); Markermeer (3) \\
Rivers & Nederrijn (6); Meuse (3) \\
Size class & Large (5); medium (5); small (5) \\
Water type & Lakes (6); rivers (9) \\
\hline
\end{tabular}



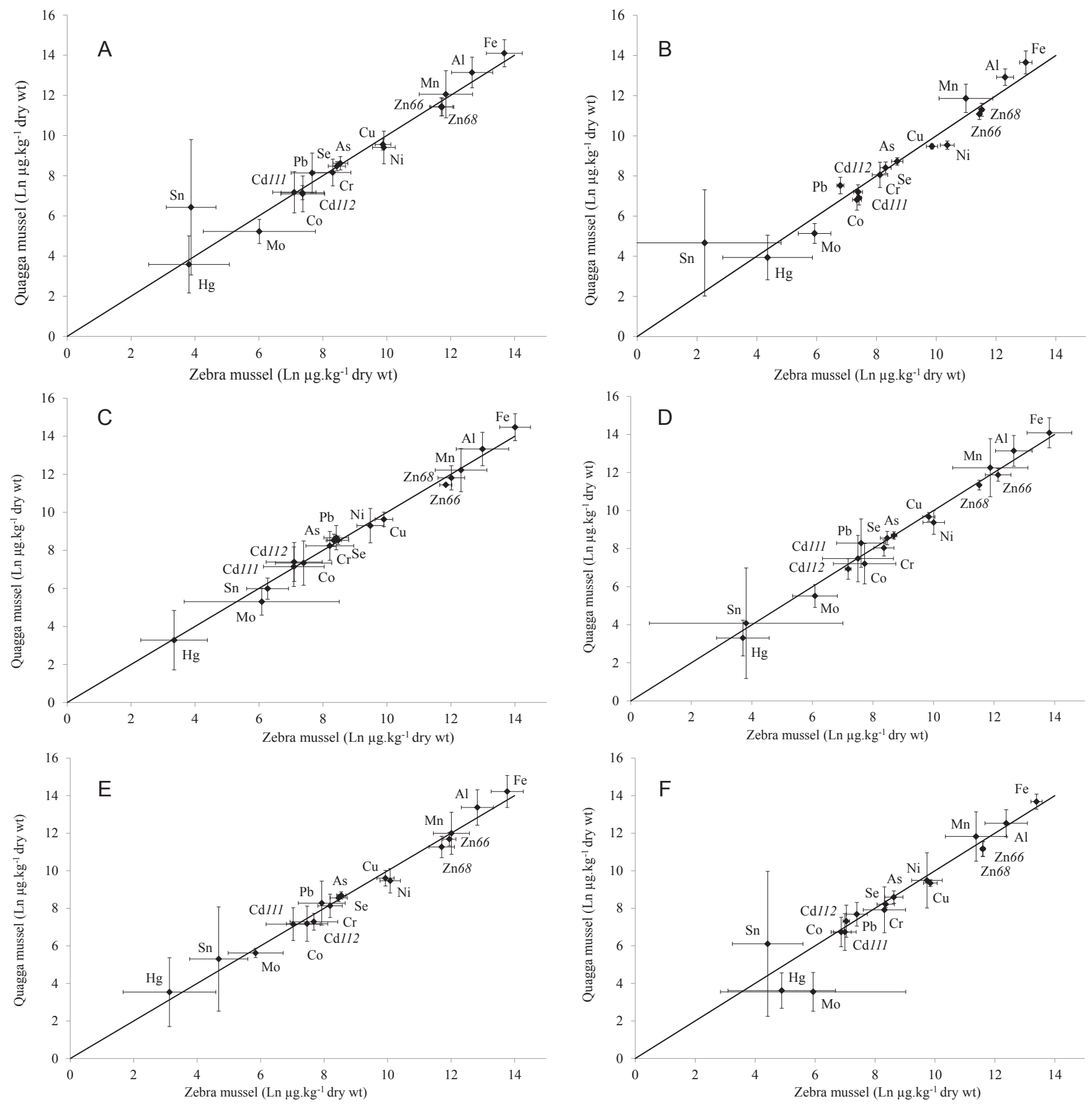

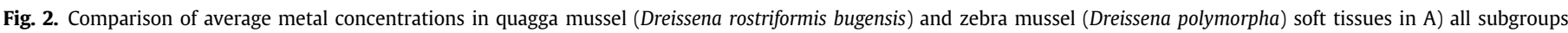
combined; B) lake water type; C) river water type; D) $<15 \mathrm{~mm}$ shell length; E) 15-22 mm shell length; F) $>22 \mathrm{~mm}$ shell length. Error bars represent Ln standard deviation.

Different habitat characteristics may explain the contrasting results shown in these studies as compared to our results. Dutch lakes are relatively shallow compared to those present in North America such as the Great Lakes. For example, the largest lake in the Netherlands, Lake IJsselmeer, has a mean depth of $4.5 \mathrm{~m}$ (Berger and Sweers, 1998). Different depth and temperature regimes may play a role in the exposure and absorption of metals in mussels (Wiesner et al., 2001; Veltman et al., 2008). When zebra and quagga mussels occur in the same lake, zebra mussels generally reach their highest densities in warm, shallow water, whereas quagga mussels occur in colder, deeper water (Dermott and Munawar, 1993; Mills et al., 1996). Clearance rate and temperature relationships are reported in dreissenid mussels and dreissenid filtering activity may be positively influenced by temperature (Reeders and Bij de Vaate, 1990; Borcherding, 1992). Therefore, the quagga mussels preference for colder, deeper water than the zebra mussel and a possible relationship between temperature and filtration rate may explain the differences in metal accumulation measured in these studies.

Apart from differences in habitat preference and characteristics, the inter-species difference in metal accumulation may be related to differences in physiological characteristics, e.g. energy expenditure, filtration and growth rate. For example, pollutant uptake in 
Table 4

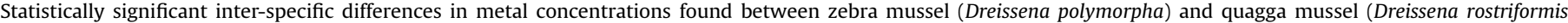
bugensis) tissues sampled in different water types, lakes and rivers.

\begin{tabular}{|c|c|c|c|}
\hline Variable & Metal & ANOVA & Mann Whitney \\
\hline Overall $^{\mathrm{a}}$ & Nickel & $\mathrm{Na}$ & $\mathrm{U}=44.00, \mathrm{z}=-2.08, P<0.05$ \\
\hline Overall $^{\mathrm{a}}$ & Copper & $\mathrm{Na}$ & $\mathrm{U}=28.00, \mathrm{z}=-2.90, P<0.05$ \\
\hline Lake water type ${ }^{\mathrm{b}}$ & Aluminium & $\mathrm{Na}$ & $\mathrm{U}=4.00, \mathrm{z}=-2.24, P<0.05$ \\
\hline Lake water type $^{\mathrm{b}}$ & Copper & $\mathrm{Na}$ & $\mathrm{U}=0.00, \mathrm{z}=-2.88, P<0.05$ \\
\hline Lake water type $^{\mathrm{b}}$ & Zinc66 & $\mathrm{Na}$ & $\mathrm{U}=0.00, \mathrm{z}=-2.88, P<0.05$ \\
\hline Lake water type $^{\mathrm{b}}$ & Cobalt & $\mathrm{Na}$ & $\mathrm{U}=2.00, \mathrm{z}=-2.56, P<0.05$ \\
\hline Lake water type ${ }^{b}$ & Iron & $\mathrm{Na}$ & $\mathrm{U}=3.00, \mathrm{z}=-2.40, P<0.05$ \\
\hline Lake water type $^{\mathrm{b}}$ & Nickel & $\mathrm{Na}$ & $\mathrm{U}=0.00, \mathrm{z}=-2.88, P<0.05$ \\
\hline Lake water type $^{\mathrm{b}}$ & Molybdenum & $\mathrm{Na}$ & $\mathrm{U}=4.00, \mathrm{z}=-2.24, P<0.05$ \\
\hline Lake water type ${ }^{\mathrm{b}}$ & Lead & $\mathrm{Na}$ & $\mathrm{U}=4.00, \mathrm{z}=-2.24, P<0.05$ \\
\hline Lake water type $^{\mathrm{b}}$ & Cadmium111 & $\mathrm{F}(1,10)=13.54, P<0.05$ & $\mathrm{Na}$ \\
\hline River water type $^{c}$ & Zinc66 & $\mathrm{Na}$ & $\mathrm{U}=0.00, \mathrm{z}=-3.13, P<0.05$ \\
\hline
\end{tabular}

Na: statistical test not applicable.

a All subgroups combined.

b Lakes combined.

c Rivers combined.

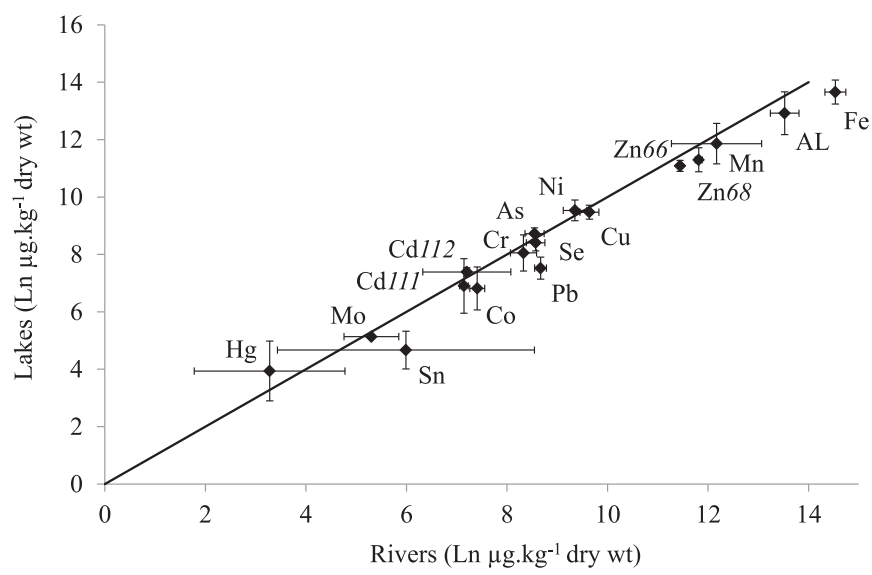

Fig. 3. Comparison of dry weight metal concentrations in the soft tissues of quagga mussels (Dreissena rostriformis bugensis) from river and lake water types.

dreissenids has been linked to filtration rate (Kraak et al., 1991; Bervoets et al., 2004; Veltman et al., 2008; Le et al., 2011). Veltman et al. (2008) attributed high uptake rate constants in mussels to their high filtration rate. However, contrasting observations of inter-species differences in filtration rate in quagga and zebra mussels have been reported. Ackerman (1999) was unable to demonstrate any inter-species difference in filtration rate. Yet, quagga mussels have been found to contain greater soft tissue dry mass than zebra mussels per unit shell length (Baldwin et al., 2002). Ackerman's (1999) observations were based on mussel length only and not corrected for inter-species differences in soft tissue mass. Diggins (2001) compared individual mussel and ashfree dry weight filtration rates and found that, in both cases, quagga mussels filtered significantly faster than zebra mussels. Baldwin et al. (2002), on the other hand, observed that when samples were corrected for soft tissue dry mass, zebra mussel clearance rates (volume of water cleared of particles per unit time as a result of filtration) were two to seven times higher than those of the quagga mussel. Higher filtration rates in zebra mussels may account for the higher metal concentrations we observed in this species. However, inter-species differences in filtration rate may depend on local conditions, mussel size class and the definition applied to mussel size.

The quagga mussel expends less energy on reproduction, shell development and respiration than the zebra mussel, allowing it to invest more energy in soft tissue growth (Stoeckmann, 2003; Casper and Johnson, 2010). Consequently, the quagga mussel is able to grow quicker than the zebra mussel (Baldwin et al., 2002; Karatayev et al.,

Table 5

Statistically significant differences in metal concentrations in the soft tissues of quagga mussels (Dreissena rostriformis bugensis) sampled in different water types: lakes and rivers (intra-species differences).

\begin{tabular}{|c|c|c|c|}
\hline Variable & Metal & ANOVA & Mann Whitney \\
\hline Water type ${ }^{a}$ & Iron & $\mathrm{F}(1,13)=19.57, P<0.05$ & $\mathrm{Na}$ \\
\hline Water type ${ }^{a}$ & Zinc66 & $\mathrm{Na}$ & $\mathrm{U}=3.00, \mathrm{z}=-2.83, P<0.05$ \\
\hline Water type ${ }^{a}$ & Zinc68 & $\mathrm{Na}$ & $\mathrm{U}=3.00, \mathrm{z}=-2.83, P<0.05$ \\
\hline Rivers $^{\mathrm{b}}$ & Cadmium111 & $\mathrm{Na}$ & $\mathrm{U}=0.00, \mathrm{z}=-2.32, P<0.05$ \\
\hline Rivers $^{\mathrm{b}}$ & Cadmium112 & $\mathrm{Na}$ & $\mathrm{U}=0.00, \mathrm{z}=-2.32, P<0.05$ \\
\hline Rivers $^{\mathrm{b}}$ & Iron & $\mathrm{Na}$ & $\mathrm{U}=0.00, \mathrm{z}=-2.32, P<0.05$ \\
\hline Rivers $^{\mathrm{b}}$ & Manganese & $\mathrm{Na}$ & $\mathrm{U}=1.00, \mathrm{z}=-2.07, P<0.05$ \\
\hline Rivers $^{\mathrm{b}}$ & Cobalt & $\mathrm{Na}$ & $\mathrm{U}=0.00, \mathrm{z}=-2.32, P<0.05$ \\
\hline Rivers $^{\mathrm{b}}$ & Nickel & $\mathrm{Na}$ & $\mathrm{U}=0.00, \mathrm{z}=-2.32, P<0.05$ \\
\hline Rivers $^{\mathrm{b}}$ & Mercury & $\mathrm{Na}$ & $\mathrm{U}=0.00, \mathrm{z}=-2.32, P<0.05$ \\
\hline Rivers $^{\mathrm{b}}$ & Tin & $\mathrm{Na}$ & $\mathrm{U}=1.00, \mathrm{z}=-2.07, P<0.05$ \\
\hline Rivers $^{\mathrm{b}}$ & Zinc66 & $\mathrm{Na}$ & $\mathrm{U}=0.00, \mathrm{z}=-2.32, P<0.05$ \\
\hline Rivers $^{\mathrm{b}}$ & Zinc68 & $\mathrm{Na}$ & $\mathrm{U}=0.00, \mathrm{z}=-2.32, P<0.05$ \\
\hline Rivers $^{\mathrm{b}}$ & Arsenic & $\mathrm{Na}$ & $\mathrm{U}=0.00, \mathrm{z}=-2.32, P<0.05$ \\
\hline Rivers $^{\mathrm{b}}$ & Selenium & $\mathrm{Na}$ & $\mathrm{U}=0.00, \mathrm{z}=-2.32, P<0.05$ \\
\hline
\end{tabular}

Na: statistical test not applicable.

a Lakes combined, rivers combined.

b Nederrijn, Meuse. 
2011). Higher growth rates in quagga mussels may, in turn, result in higher growth dilution when compared to zebra mussels, leading to a decrease in body metal concentration with age and size (Carrasco et al., 2008; Le et al., 2011). Moreover, differences in metal concentrations between other mussel species have been related to differences in growth rate rather than to any direct difference in metabolism (Lobel et al., 1990). However, in a study of lake Erie, North America, growth rates were shown to be very similar in quagga and zebra mussels, which corresponds with the lack of statistically significant inter-species differences in metal concentrations observed in this lake (Macisaac, 1994; Rutzke et al., 2000).

\subsection{Differences in mussel soft tissue concentrations with mussel} size

Many Eurasian predatory fish species, including the roach (Rutilus rutilus), are highly selective of prey size (Nagelkerke and Sibbing, 1996). A change in dominance from zebra mussels to invading quagga mussels may result in changes in the trophic transfer of metals that differs between mussel size classes. However, in this study, no inter- or intra-species differences in metal concentration within size classes were found. In literature, some relationships have been reported between shell size and metal concentrations. A study of the Niagara River in Canada indicated that larger quagga and zebra mussels (i.e., $16-25 \mathrm{~mm}$ ) generally had higher tissue concentrations than smaller mussels $(<15 \mathrm{~mm}$ length) (Richman and Somers, 2005). However, differences in tissue concentrations between size classes were present only for cadmium, copper and manganese, making these results inconclusive. Mills et al. (1993) examined zebra and quagga mussels in lake Ontario, Canada, and found significant differences in manganese concentrations between large and small quagga mussels. In both lakes Erie and Ontario, Canada, Rutzke et al. (2000) found no significant differences between quagga and zebra mussel size classes for a wide range of metals. A possible explanation for the lack of statistically significant results between quagga size classes may be that continued metal accumulation and higher filtration rates in larger mussels are counter balanced by growth dilution. Based on these results, no conclusions can be drawn regarding changes in trophic transfer of metals based on prey size following a change in mussel dominance to the invasive quagga mussel.

\subsection{Differences in metal concentration in the soft tissues of mussels between water types}

Invasive mussels may accumulate metals to a higher degree in certain water types compared to others, leading to possible differences in trophic transfer of metals between water types in the event of invasion and selection of quagga mussels by predators. Lower metal concentrations observed in the soft tissues of mussels sampled from lakes compared to those from rivers may be explained by lower metal contamination/pollution levels in lake water compared to river water at the sampling locations. Higher concentrations of metals have been observed near river mouths in lakes compared to other locations within the same lakes suggesting that river water may carry higher concentrations of pollutants than lake water (Rosales-Hoz et al., 2000; Kishe and Machiwa, 2003). Current velocity and turbulent flow may be higher in rivers than lakes, for example because of intensive shipping. Resulting sediment re-suspension may increase metal concentrations in the water column (Vuori, 1995; Rosales-Hoz et al., 2000; Ji et al., 2002). Sediment re-suspension may increase metal availability and lead to higher mussel soft tissue metal concentrations in rivers.

Significantly higher concentrations of the majority of metals tested in quagga mussels taken from the river Meuse compared to the river Nederrijn may be related to higher levels of metal pollution in the river Meuse. This may be applicable for the period from 2008 to 2010 when zinc and cadmium were present in higher average concentrations in the river Meuse at Eijsden than in the river Rhine at Lobith (Rijkswaterstaat, 2014). However, this explanation does not hold for copper. Average copper concentrations were similar in the Rhine and the river Meuse for the same time period (Rijkswaterstaat, 2014; ICPR, 2014). Local variations in environmental metal concentration and differences in metal accumulation mechanisms may explain the disagreement between metal concentrations in water and mussel soft tissue concentration (Marie et al., 2006; Veltman et al., 2008). Intra-species differences in tissue metal concentrations between individual rivers, and river and lake water types, indicate that predator habitat preference may be an important consideration when assessing the consequences of aquatic bioinvasions for the trophic transfer of metals.

\subsection{Implications for secondary poisoning}

A change in species dominance from zebra to the invasive quagga mussel may alter the trophic transfer of metals as a result of inter-species differences in metal concentrations.

The similarity in inter-species selenium concentration, and the significantly lower concentrations of copper (overall) and cadmium111, copper and zinc66 (in lakes) found in the quagga mussel suggest that, in general, a dominance shift and resulting dietary switch from zebra to quagga mussels will reduce exposure of predator species to a number of metals of concern at our sampling sites. Moreover, further reductions in exposure may occur if predator species exhibit a dietary preference for quagga mussels following a dominance shift from zebra to quagga mussels. The quagga mussel often has a larger soft tissue mass relative to shell size and a thinner shell than the zebra mussel (Baldwin et al., 2002; Zhulidov et al., 2006), which may be favoured by dreissenid predators. Eurasian cyprinids, some species of goby and whitefish are highly selective of molluscan prey (Starobogatov, 1994), and selective fish predation may explain the widespread decline of the quagga mussel relative to the zebra mussel in the Don and Manych River systems in Russia (Zhulidov et al., 2006). In conclusion, in the event of a switch in dominance from the zebra to the invasive quagga mussel, lower concentrations of copper, cadmium and zinc measured in our analysis of quagga mussels may contribute to the overall reduction in trophic transfer of these metals, adding to metal exposure reduction resulting from general improvements in water quality (Durance and Ormerod, 2009).

\section{Acknowledgements}

We would like to thank the Invasive Alien Species Team (TIE) of the Netherlands Food and Consumer Product Safety Authority (NVWA), Ministry of Economic Affairs (TRCPD/2010/3092) and the Schure Beijerinck-Popping fund (SBP2012/54) for financial support, Jelle Eygensteyn for his assistance in carrying out the ICP MS analysis, Aryan Ransijn for his help during field work and metal analyses and two anonymous reviewers who provided many constructive comments.

\section{References}

Ackerman, J.D., 1999. Effect of velocity on the filter feeding of dreissenid mussels (Dreissena polymorpha and Dreissena bugensis): implications for trophic dynamics. Can. J. Fish. Aquat. Sci. 56, 1551-1561.

Baldwin, B.S., Mayer, M.S., Dayton, J., Pau, N., Mendilla, J., Sullivan, M., Moore, A Ma, A., Mills, E.L., 2002. Comparative growth and feeding in zebra and quagga mussels (Dreissena polymorpha and Dreissena bugensis): implications for North American lakes. Can. J. Fish. Aquat. Sci. 59, 680-694. 
Berger, C., Sweers, H., 1988. The IJsselmeer and its phytoplankton-with special attention to the suitability of the lake as a habitat for Oscillatoria agardhii Gom. J. Plankton Res. 10, 579-599.

Bervoets, L., Voets, J., Chu, S.G., Covaci, A., Schepens, P., Blust, R., 2004. Comparison of accumulation of micropollutants between indigenous and transplanted zebra mussels (Dreissena polymorpha). Environ. Toxicol. Chem. 23, 1973-1983.

Bij de Vaate, A., 2010. Populatiedynamica van Driehoeks- en Quaggamosselen in het Marker- en IJsselmeer: Resultaten van Onderzoek Uitgevoerd in 2009. Waterfauna Hydrobiologisch Adviesbureau, Lelystad.

Bij de Vaate, A., Van der Velde, G., Leuven, R.S.E.W., Heiler, K.C.M., 2014. Spread of the quagga mussel, Dreissena rostriformis bugensis in Western Europe. In: Nalepa, T.F., Schloesser, D.W. (Eds.), Quagga and Zebra Mussels: Biology, Impacts, and Control, second ed. CRC Press, Taylor \& Francis Group, Boca Raton, Florida, pp. 83-92.

Bonhof, G.H., Nieuwenhuijzen, A.J.L., Koeman, T., Wolters, G., 2009. Effecten Oeververdediging in de Lek bij Everdingen en Steenwaard op de Macrofauna Levensgemeenschap Meetjaar 2008. Koeman en Bijkerk bv, Haren.

Borcherding, J., 1992. Another early warning system for the detection of toxic discharges in the aquatic environment based on valve movements of the freshwater mussel Dreissena polymorpha. In: Neumann, D., Jenner, H.A. (Eds.), The Zebra Mussel Dreissena polymorpha: Ecology, Biological Monitoring and First Applications in Water Quality Management. Gustav Fischer Verlag, Stuttgart, pp. 127-146.

Carrasco, L., Diez, S., Soto, D.X., Catalan, J., Bayona, J.M., 2008. Assessment of mercury and methylmercury pollution with zebra mussel (Dreissena polymorpha) in the Ebro River (NE Spain) impacted by industrial hazardous dumps. Sci. Total Environ. 407, 178-184.

Casper, A.F., Johnson, L.E., 2010. Contrasting shell/tissue characteristics of Dreissena polymorpha and Dreissena bugensis in relation to environmental heterogeneity in the St. Lawrence River. J. Great Lakes Res. 36, 184-189.

Custer, C.M., Custer, T.W., 2000. Organochlorine and trace element contamination, in wintering and migrating diving ducks in the southern Great Lakes, USA, since the zebra mussel invasion. Environ. Toxicol. Chem. 19, 2821-2829.

Custer, C.M., Custer, T.W., Anteau, M.J., Afton, A.D., Wooten, D.E. 2003. Trace elements in lesser scaup (Aythya affinis) from the Mississippi flyway. Ecotoxicology $12,47-54$.

De Rooij, J., Munts, R., Achterkamp, B., Kersbergen, A., 2009. Macrozoöbenthosonderzoek Nevengeulen 2009 Bakenhof, Gameren, Klompenwaard, Oude Waal en Vreugderijkerwaard. Bureau Waardenburg bv, Culemborg.

De Kock, W.C., Bowmer, C.T., 1993. Bioaccumulation, biological effects, and food chain transfer of contaminants in the zebra mussel (Dreissena polymorpha). In: Nalepa, T., Schloesser, D. (Eds.), Zebra Mussels: Biology, Impacts, and Control. Lewis Publishers, USA, pp. 503-533.

Dermott, R., Munawar, M., 1993. Invasion of Lake Erie offshore sediments by Dreissena, and its ecological implications. Can. J. Fish. Aquat. Sci. 50, 2298-2304.

Diggins, T.P., 2001. A seasonal comparison of suspended sediment filtration by quagga (Dreissena bugensis) and zebra (D. polymorpha) mussels. J. Great Lakes Res. 27, 457-466.

Durance, I., Ormerod, S.J., 2009. Trends in water quality and discharge confound long-term warming effects on river macroinvertebrates. Freshwater Biol. 54, $388-405$.

European Commission, 2011. The EU Biodiversity Strategy to 2020. http://ec.europa eu/environment/nature/info/pubs/docs/brochures/2020\%20Biod\%20brochure\% 20final\%20lowres.pdf (Last accessed 03.11.14).

European Commission, 2013. Proposal for a Regulation of the European Parliament and of the Council on the Prevention and Management of the Introduction and Spread of Invasive Alien Species. http://eur-lex.europa.eu/legal-content/EN/ TXT/PDF/?uri=CELEX:52013PC0620\&from=EN (Last accessed 03.11.14).

Flemming, C.A., Trevors, J.T., 1989. Copper toxicity and chemistry in the environment - a review. Water Air Soil Pollut. 44, 143-158.

Gonzalez, M.J., Downing, A., 1999. Mechanisms underlying amphipod responses to zebra mussel (Dreissena polymorpha) invasion and implications for fishamphipod interactions. Can. J. Fish. Aquat. Sci. 56, 679-685.

Heiler, K.C.M., Brandt, S., Albrecht, C., Hauffe, T., Wilke, T., 2012. A new approach for dating introduction events of the quagga mussel (Dreissena rostriformis bugensis). Biol. Invasions 14, 1311-1316.

Hogan, L.S., Marschall, E., Folt, C., Stein, R.A., 2007. How non-native species in Lake Erie influence trophic transfer of mercury and lead to top predators. J. Great Lakes Res. 33, 46-61.

ICPR (International Commission for the Protection of the Rhine), 2014. http://www. iksr.org/index.php?id $=58 \& \mathrm{~L}=3$ (Last accessed 03.11.14).

ISSG (Invasive Species Specialist Group), 2000. IUCN Guidelines for the Prevention of Biodiversity Loss Caused by Alien Invasive Species. http://www.issg.org/pdf/ guidelines_iucn.pdf (Last accessed 03.11.14)

Ji, Z.G., Hamrick, J.H., Pagenkopf, J., 2002. Sediment and metals modeling in shallow river. J. Environ. Eng.-Asce 128, 105-119.

Johns, C., Timmerman, B.E., 1998. Total cadmium, copper, and zinc in two Dreissenid mussels, Dreissena polymorpha and Dreissena bugensis, at the outflow of Lake Ontario. J. Great Lakes Res. 24, 55-64.

Karatayev, A.Y., Mastitsky, S.E., Padilla, D.K., Burlakova, L.E., Hajduk, M.M., 2011 Differences in growth and survivorship of zebra and quagga mussels: size matters. Hydrobiologia 668, 183-194.

Katsanevakis, S., Genovesi, P., Gaiji, S., Hvid, H.N., Roy, H., Nunes, A.L., Aguado, F.S., Bogucarskis, K., Debusscher, B., Deriu, I., 2013. Implementing the European policies for alien species: networking, science, and partnership in a complex environment. Manage. Biol. Invasions 4, 3-6.

Kelly, D.W., Herborg, L.-M., MacIsaac, H.J., 2010. Ecosystem changes associated with Dreissena invasions: recent developments and emerging issues. In: Van der Velde, G., Rajagopal, S., Bij de Vaate, A. (Eds.), The Zebra Mussel in Europe, pp. 199-210. Backhuys Publishers, Leiden/Margraf Publishers, Weikersheim.

Kishe, M.A., Machiwa, J.F., 2003. Distribution of heavy metals in sediments of Mwanza Gulf of Lake Victoria, Tanzania. Environ. Int. 28, 619-625.

Kraak, M.H.S., Scholten, M.C.T., Peeters, W.H.M., Dekock, W.C., 1991. Biomonitoring of heavy-metals in the western-European rivers Rhine and Meuse using the fresh-water mussel Dreissena polymorpha. Environ. Pollut. 74, 101-114.

Kwon, T.D., Fisher, S.W., Kim, G.W., Hwang, H., Kim, J.E., 2006. Trophic transfer and biotransformation of polychlorinated biphenyls in zebra mussel, round goby, and smallmouth bass in Lake Erie, USA. Environ. Toxicol. Chem. 25, 1068-1078.

Le, T.T.Y., Leuven, R.S.E.W., Hendriks, A.J., 2011. Modeling metal bioaccumulation in the invasive mussels Dreissena polymorpha and Dreissena rostriformis bugensis in the rivers Rhine and Meuse. Environ. Toxicol. Chem. 30, 2825-2830.

Lobel, P.B., Belkhode, S.P., Jackson, S.E., Longerich, H.P., 1990. Recent taxonomic discoveries concerning the mussel Mytilus - implications for biomonitoring. Arch. Environ. Contam. Toxicol. 19, 508-512.

Macisaac, H.J., 1994. Comparative growth and survival of Dreissena polymorpha and Dreissena bugensis, exotic mollusks introduced to the Great-Lakes. J. Great Lakes Res. 20, 783-790.

Marie, V., Baudrimont, M., Boudou, A., 2006. Cadmium and zinc bioaccumulation and metallothionein response in two freshwater bivalves (Corbicula fluminea and Dreissena polymorpha) transplanted along a polymetallic gradient. Chemosphere 65, 609-617.

Matthews, J., Van der Velde, G., Bij de Vaate, A., Collas, F.P.L., Koopman, K.R., Leuven, R.S.E.W., 2014. Rapid range expansion of the invasive quagga mussel in relation to zebra mussel presence in The Netherlands and Western Europe. Biol. Invasions 16, 23-42.

Mills, E.L., Roseman, E.F., Rutzke, M., Gutenmann, W.H., Lisk, D.J., 1993. Contaminant and nutrient element levels in soft-tissues of zebra and quagga mussels from waters of southern Lake Ontario. Chemosphere 27, 1465-1473.

Mills, E.L., Rosenberg, G., Spidle, A.P., Ludyanskiy, M., Pligin, Y., May, B., 1996. A review of the biology and ecology of the quagga mussel (Dreissena bugensis), a second species of freshwater dreissenid introduced to North America. Am. Zoologist 36, 271-286.

Mitchell, M.J., Mills, E.L., Idrisi, N., Michener, R., 1996. Stable isotopes of nitrogen and carbon in an aquatic food web recently invaded by Dreissena polymorpha (Pallas). Can. J. Fish. Aquat. Sci. 53, 1445-1450.

Mörtl, M., Werner, S., Rothhaupt, K.-O., 2010. Effects of predation by wintering water birds on zebra mussels and on associated macroinvertebrates. In: Van der Velde, G., Rajagopal, S., Bij de Vaate, A. (Eds.), The Zebra Mussel in Europe, pp. 239-250. Backhuys Publishers, Leiden/Margraf Publishers, Weikersheim.

Mueting, S.A., Gerstenberger, S.L., 2010. Mercury concentrations in quagga mussels, Dreissena bugensis, from lakes Mead, Mohave and Havasu. Bull. Environ. Contam. Toxicol. 84, 497-501.

Nagelkerke, L.A.J., Sibbing, F.A., 1996. Efficiency of feeding on zebra mussel (Dreissena polymorpha) by common bream (Abramis brama), white bream (Blicca bjoerkna), and roach (Rutilus rutilus): the effects of morphology and behavior. Can. J. Fish. Aquat. Sci. 53, 2847-2861.

Neumann, D., Jenner, H.A. (Eds.), 1992. The Zebra Mussel Dreissena polymorpha. Ecology, Biological Monitoring and First Applications in the Water Quality Management. Gustav Fischer, Stuttgart. Limnologie aktuell, Band 4.

Noordhuis, R.R., Van Eerden, M.R., Roos, M., 2010. Crash of zebra mussel, transparency and water bird populations in Lake Markermeer. In: Van der Velde, G., Rajagopal, S., Bij de Vaate, A. (Eds.), The Zebra Mussel in Europe, pp. 265-277. Backhuys Publishers, Leiden/Margraf Publishers, Weikersheim.

Petrie, S.A., Badzinski, S.S., Drouillard, K.G., 2007. Contaminants in lesser and greater scaup staging on the lower Great Lakes. Arch. Environ. Contam. Toxicol. 52, $580-589$.

Petrie, S.A., Knapton, R.W., 1999. Rapid increase and subsequent decline of zebra and quagga mussels in Long Point Bay, Lake Erie: possible influence of waterfowl predation. J. Great Lakes Res. 25, 772-782.

Reeders, H., Bij de Vaate, A., 1990. Zebra mussels (Dreissena polymorpha): a new perspective for water quality management. Hydrobiologia 200, 437-450.

Richman, L., Somers, K., 2005. Can we use zebra and quagga mussels for biomonitoring contaminants in the Niagara River? Water Air Soil Pollut. 167, 155-178.

Rijkswaterstaat, 2014. Waterbase. http://live.waterbase.nl/waterbase_wns.cfm? taal $=$ nl (Last accessed 03.11.14).

Rosales-Hoz, L., Carranza-Edwards, A., Lopez-Hernandez, M., 2000. Heavy metals in sediments of a large, turbid tropical lake affected by anthropogenic discharges. Environ. Geol. 39, 378-383.

Rutzke, M.A., Gutenmann, W.H., Lisk, D.J., Mills, E.L., 2000. Toxic and nutrient element concentrations in soft tissues of zebra and quagga mussels from Lakes Erie and Ontario. Chemosphere 40, 1353-1356.

Santore, R.C., Mathew, R., Paquin, P.R., DiToro, D., 2002. Application of the biotic ligand model to predicting zinc toxicity to rainbow trout, fathead minnow, and Daphnia magna. Comp. Biochem. Physiol. C-Toxicol. Pharmacol. 133, 271-285.

Scheuhammer, A.M., 1987. The chronic toxicity of aluminum, cadmium, mercury, and lead in birds - a review. Environ. Pollut. 46, 263-295.

Starobogatov, J.I., 1994. Freshwater Zebra Mussel Dreissena polymorpha (Pall.) (Bivalvia, Dreissenidae). In: Systematics, Ecology, Practical Meaning. Nauka 
Publishing House, Moscow.

Stoeckmann, A., 2003. Physiological energetics of Lake Erie dreissenid mussels: a basis for the displacement of Dreissena polymorpha by Dreissena bugensis. Can. J Fish. Aquat. Sci. 60, 126-134.

Van der Velde, G., Hermus, K., Van der Gaag, M., Jenner, H.A., 1992. Cadmium, zinc and copper in the body, byssus and shell of the mussels, Mytilopsis leucophaeta and Dreissena polymorpha in the brackish Noordzeekanaal of the Netherlands. In: Neumann, D., Jenner, H.A. (Eds.), The Zebra Mussel Dreissena polymorpha, Ecology, Biological Monitoring and First Applications in the Water Quality Management. Gustav Fischer, Stuttgart. Limnologie aktuell, Band 4.

Van Eerden, M.R., De Leeuw, J.J., 2010. How Dreissena sets the winter scene for water birds: dynamic interactions between diving ducks and zebra mussels. In: Van der Velde, G., Rajagopal, S., Bij de Vaate, A. (Eds.), The Zebra Mussel in Europe, pp. 251-264. Backhuys Publishers, Leiden/Margraf Publishers, Weikersheim.

Veltman, K., Huijbregts, M.A.J., Van Kolck, M., Wang, W.X., Hendriks, A.J., 2008. Metal bioaccumulation in aquatic species: quantification of uptake and elimination rate constants using physicochemical properties of metals and physiological characteristics of species. Environ. Sci. Technol. 42, 852-858.

Vuori, K.M., 1995. Direct and indirect effects of iron on river ecosystems. Ann. Zool. Fenn. 32, 317-329.

Ward, J.M., Ricciardi, A., 2010. Community-level effects of co-occurring native and exotic ecosystem engineers. Freshw. Biol. 55, 1803-1817.

Watkins, J.M., Dermott, R., Lozano, S.J., Mills, E.L., Rudstam, L.G., Scharold, J.V., 2007. Evidence for remote effects of dreissenid mussels on the amphipod Diporeia: analysis of Lake Ontario benthic surveys, 1972-2003. J. Great Lakes Res. 33, 642-657.

Wiesner, L., Gunther, B., Fenske, C., 2001. Temporal and spatial variability in the heavy-metal content of Dreissena polymorpha (Pallas) (Mollusca : Bivalvia) from the Kleines Haff (northeastern Germany). Hydrobiologia 443, 137-145.

Zhulidov, A.V., Nalepa, T.F., Kozhara, A.V., Zhulidov, D.A., Gurtovaya, T.Y., 2006. Recent trends in relative abundance of two dreissenid species, Dreissena polymorpha and Dreissena bugensis in the lower Don River system, Russia. Arch. für Hydrobiol. 165, 209-220. 